\title{
Salinity and subsequent freshwater influences on the growth, biomass, and polyisoprenoids distribution of Rhizophora apiculata seedlings
}

\author{
MOHAMMAD BASYUNI ${ }^{1,2,}$, MASRIDA WASILAH ${ }^{1}$, POPPY ANJELISA ZAITUN HASIBUAN ${ }^{3}$, \\ NURDIN SULISTIYONO ${ }^{1,2}$, SUMARDI ${ }^{4}$, YUNTHA BIMANTARA ${ }^{1}$, RAHMAH HAYATI ${ }^{1}$, HIROSHI SAGAMI ${ }^{5}$, \\ HIROSUKE OKU6 \\ ${ }^{1}$ Department of Forestry, Faculty of Forestry, Universitas Sumatera Utara, Jl. Tri Dharma Ujung No. 1 Medan, North Sumatra, 20155, Indonesia. \\ Tel./fax: +62-61-820-1920. `email: m.basyuni@usu.ac.id \\ ${ }^{2}$ Mangrove and Bio-Resources Group, Center of Excellence for Natural Resources-Based Technology, Universitas Sumatera Utara. Padang Bulan, \\ Medan 20155, North Sumatra, Indonesia \\ ${ }^{3}$ Faculty of Pharmacy, Universitas Sumatera Utara. Medan 20155, North Sumatra, Indonesia \\ ${ }^{4}$ Faculty of Pharmacy, University of Tjut Nyak Dhien, Jl. Rasmi No. 28 Medan, 20123, North Sumatra, Indonesia \\ ${ }^{5}$ Institute of Multidisciplinary Research for Advanced Material, Tohoku University. 2-1-1 Katahira, Aoba-ku, Sendai, 980-8577, Japan \\ ${ }^{6}$ Molecular Biotechnology Group, Tropical Biosphere Research Center, University of the Ryukyus. 1 Senbaru, Nishihara Okinawa 903-0213, Japan
}

Manuscript received: 24 November 2018. Revision accepted: 31 December 2018

\begin{abstract}
Basyuni M, Wasilah M, Hasibuan PAZ, Sulistiyono N, Sumardi, Bimantara Y, Hayati R, Sagami H, Oku H. 2019. Salinity and subsequent freshwater influences on the growth, biomass, and polyisoprenoids distribution of Rhizophora apiculata seedlings. Biodiversitas 20: 388-395. This study described the growth, biomass, and polyisoprenoids (polyprenol and dolichol) distribution of Rhizophora apiculata seedlings under saline and subsequent fresh water treatment. Propagules of $R$. apiculata were collected from Pulau Sembilan, Langkat, North Sumatra and were grown in $0.0 \%, 0.5 \%, 1.5 \%, 2.0 \%$, and $3.0 \%$ salt concentrations for three months. After three months planted in a glass house, R. apiculata seedlings were divided into two groups and grown for another three months. The first group was continuously grown under the saline condition and the second was moved to fresh water to recover from the saline condition. The leaves, stems, and roots of $R$. apiculata seedlings were harvested after six months of cultivation. Polyisoprenoids alcohol was isolated from the leaves and roots of $R$. apiculata seedlings and analyzed using two-dimensional thin layer chromatography. Growth parameters measured were height and diameter of $R$. apiculata seedlings. The height of $R$. apiculata seedlings was significantly affected by salinity levels of $2.0 \%, 3.0 \%$ and $3.0 \% \rightarrow 0.0 \%$. The arrow $(\rightarrow)$ denoted fresh water recovery treatment. The best height and diameter of $R$. apiculata seedlings were observed in $0.5 \%$ salt concentration. Salinity treatment and re-adaptation into freshwater significantly influenced the leaves area $(2.0 \%, 3.0 \%$ and $3.0 \% \rightarrow 0.0 \%)$, fresh weight of stem $(3.0 \%$ and $3 \% \rightarrow 0.0 \%)$ and stem dry weight $(3 \% \rightarrow 0.0 \%)$. Distribution of polyprenols and dolichols in the leaves and roots of $R$. apiculata seedlings were categorized as type I, where dolichol was dominant over polyprenol. Under salinity and subsequent fresh water recovery treatments $(0.0 \%, 1.5 \%, 1.5 \%$ $\rightarrow 0.0 \%, 3.0 \%$, and $3.0 \% \rightarrow 0.0 \%$ ), the carbon chain length of dolichol in the leaves and in the roots was, respectively, $\mathrm{C}_{85}-\mathrm{C}_{100}, \mathrm{C}_{85}-$ $\mathrm{C}_{100}, \mathrm{C}_{85}-\mathrm{C}_{105}, \mathrm{C}_{85}-\mathrm{C}_{100}, \mathrm{C}_{85}-\mathrm{C}_{95}$ and $\mathrm{C}_{85}-\mathrm{C}_{105}, \mathrm{C}_{85}-\mathrm{C}_{105}, \mathrm{C}_{85}-\mathrm{C}_{105}, \mathrm{C}_{85}-\mathrm{C}_{110}, \mathrm{C}_{85}-\mathrm{C}_{100}$. These data suggested the significant role of polyisoprenoids in mangrove plants to withstand salt stress and or water stress.
\end{abstract}

Keywords: Rhizophora apiculata, polyisoprenoid, rehabilitation, salinity, water stress

\section{INTRODUCTION}

Mangrove forests are one of most productive ecosystems in the world as they can enhance coastal waters, produce commercial forest products, shield coastlines, and promote coastal fisheries (Kathiresan and Bingham 2001). However, mangroves exist under conditions of fresh water to hypersaline, extreme tides, strong winds, high temperatures, muddy, and anaerobic soils. There may be no other group of plants with such well developed morphological, biological, ecological, and physiological adaptations to severe conditions (Kathiresan dan Bingham 2001; Parida and Jha 2010; Basyuni et al. 2012a).

Mangroves occupy $0.7 \%$ of the total area of the world's entire tropical forest area, a significant area belongs to Indonesia (Giri et al. 2011). Mangroves are also tolerant to saline soil and saline water conditions (Parida and Jha 2010). Although mangroves are well known to produce secondary metabolites including polyisoprenoid alcohols, the physiological function of these compounds remains to be elucidated (Basyuni et al. 2016, 2017a, 2018a). Polyisoprenoid is a secondary metabolite compound with a linear polymer unit of five carbon chains found in almost all living cells (Swiezewska and Danikiewicz 2005; Sagami et al. 2018). Our previous studies have shown that the salinity increased the triterpenoid content and triterpenoid synthase genes in mangrove seedlings (Basyuni et al. 2009, 2012a,b). By contrast, salinity decreased the mangrove seedling growth (Basyuni et al. 2009, 2012a,b, 2014, 2018b). These studies suggested the complexity and diversity of mangrove species. Investigating the salt tolerant mechanism of species is, therefore, essential to be carried out. The salinity treatments shifted the polyisoprenoid content in mangroves seedlings (Basyuni et al. 2017b). This study, therefore, was aimed to describe the growth, biomass and polyisoprenoids distribution of $R$. apiculata seedlings under the saline condition and subsequent fresh water treatment to extend our previous works. 


\section{MATERIALS AND METHODS}

\section{Plant materials}

Ripen and healthy propagules of $R$. apiculata Blume (Rhizophoraceae) were collected from Pangkalan Susu, Langkat, Sumatera Utara, Indonesia in September. Ripen propagules of $R$. apiculata were known to have green to brown hypocotyl and cotyledonary collar red color, 20-25 $\mathrm{cm}$ long and 1.3-1.7 $\mathrm{cm}$ diameter. The propagule surface was warty and relatively smooth. Leaves, stems, and roots of $R$. apiculata seedlings were harvested from the greenhouse of Faculty of Agriculture, University of Sumatera Utara. All fresh samples were stored until the plant materials were used for analysis.

\section{Instrumentation}

The instruments used in this study included S/Mill-E salinity refractometer, chamber chromatography (SigmaAldrich), a water bath (Scientific laboratory), and an oven (Memmert).

\section{Chemicals}

A mixture of dolichol $\left(\mathrm{C}_{90}-\mathrm{C}_{105}\right)$ standard compound was isolated from horse testicles together with a mix of polyprenol $\left(\mathrm{C}_{90}-\mathrm{C}_{100}\right)$ from Malus sp. (Swierzewski and Danikiewicz 2005). A dolichol $\left(\mathrm{C}_{95}-\mathrm{C}_{110}\right)$ standard mixture derived from skipjack tuna livers (Ishiguro et al. 2014) was also used in this study. The identification of the polyisoprenoids family corresponding to polyprenols or dolichols was performed in at least three independent experiments. 60 TLC silica gel plates and reversed-phase RP-18 HPTLC silica plates and the other chemicals and solvents were obtained from Merck.

\section{Procedures}

Rhizophora apiculata propagules cultivation

Propagules of $R$. apiculata were planted in bottle pots filled with sand under several salinity level treatments for three months with exposure to room temperature and sunlight in a greenhouse of Faculty of Agriculture, University of Sumatera Utara, Medan, Indonesia. An artificial seawater solution was prepared by dissolving a commercial salt powder (Marine Salts) to adjust the salinity concentrations to $0.5 \%, 1.5 \%, 2.0 \%$, and $3.0 \%$ (equal to seawater level) according to the manufacturer's protocol. The control $(0.0 \%$ salt concentration) was made from fresh water. Each pot was irrigated with $1000 \mathrm{~mL}$ artificial seawater solution. The salinity in this study was defined as the mass of salt powder/mass of solution (Basyuni et al. $2012 \mathrm{a} ; 2017 \mathrm{~b})$. In each pot, the salt concentration treatment was checked every week during the experiments using an S/Mill-E salinity refractometer and each pot with various salt concentration was replaced with freshly prepared seawater solution to maintain a constant salt concentration throughout the study.

After three months of cultivation under varying salinity treatment, the seedlings were then divided into two treatment groups, and grown for another three months: one group was grown continuously in a salt solution, and the other was in fresh water to recover from the salinity effect.
At this step, freshwater was applied to the second group several times to leach the salinity solution from the root systems before the re-adaptation period to freshwater was started. After six months of growth, the $R$. apiculata seedlings were harvested and washed, and the leaves, shoots, and roots were stored at $-4{ }^{\circ} \mathrm{C}$ for further analysis.

\section{Observation of parameters}

Parameters observed/measured in the present study included growth parameters (stem height and diameter), number of leaves, leaf area, biomass, and polyisoprenoid alcohols of $R$. apiculata.

\section{Growth measurement}

The growth of $R$. apiculata seedlings under various salt concentrations and subsequent fresh water recovery was determined based on stem height and stem diameter after six months of cultivation.

\section{Number of leaves and leaf area measurement}

The number of leaves was counted after six months of cultivation before harvesting. Leaf area was measured on two fully expanded upper leaves of the control treatment. Leaves of salt treated and recovered seedlings were digitally scanned to quantify leaf area using ImageJ software (Scheneider et al. 2012).

\section{Biomass measurement}

A destructive sampling technique was used to determine biomass as previously reported (Basyuni et al. 2014). Fresh $R$. apiculata seedlings were portioned into leaf, stem, and root components and then dried in an oven. Biomass was measured from dry weight of leaves, stems, and roots which were determined separately on an analytical balance after drying in an oven at $75^{\circ} \mathrm{C}$ for 48 hours as earlier described (Basyuni et al. 2017a).

\section{Isolation of polyisoprenoid alcohols}

Leaves and roots $R$. apiculata seedlings were dried at a temperature of $60^{\circ} \mathrm{C}-75^{\circ} \mathrm{C}$ for $1-2$ days. The dried leaves and roots were crushed into fine powder and immersed in chloroform/methanol (2: 1, vol/vol) solvent for 48 hours (Basyuni et al. 2016). Lipid extracts from leaves and roots of $R$. apiculata seedlings were saponified at $65^{\circ} \mathrm{C}$ for 24 hours in $0.45 \mathrm{~g} \mathrm{KOH}, 2 \mathrm{ml}$ ethanol, and $2 \mathrm{ml}$ aquadest. NSL (non-saponifiable lipids) leaves and roots of R.apiculata seedlings were extracted with n-hexane and ready to analyze as previously described (Kurisaki et al. 1997; Sagami et al. 1992; Basyuni et al. 2017a, 2018a). Polyisoprenoid content of $R$. apiculata leaves and roots under $2.0 \%$ and $2.0 \% \rightarrow 0.0 \%$ were not determined in the current study due to insufficient samples for measurement.

\section{Two-plate thin layer chromatography (2P TLC) investigation}

The first dimension of TLC was performed for 60 minutes on a silica-gel glass plate $(20 \mathrm{~cm} \times 3 \mathrm{~cm})$ with toluene-ethyl acetate (9:1) solvent as earlier described (Sagami et al. 1992; Basyuni et al. 2018a). The longitudinal border of the first dimension TLC place with $1 \mathrm{~cm}$ width 
and central part of reversed phase C-18 TLC was imposed with two magnetic bars $(4.0 \mathrm{~cm} \times 1.1 \mathrm{~cm} \times 0.8 \mathrm{~cm})$ facing each gel position. The bound TLC plate was developed to the first dimension to convert polyprenol and dolichol to concentration zone of reversed phase TLC plate.

The second dimension of reversed phase RP-18 TLC silica-gel was done by using acetone for 30 minutes. The location of polyisoprenoid alcohol was divided and generated by 2P-TLC silica-gel, then classified and visualized with iodine vapor. The chromatographic images obtained were scanned. The polyprenol and dolichol concentrations detected in RP-18 HPTLC were measured using ImageJ with the standard dolichol and polyprenol as references (Scheneider et al. 2012).

\section{Statistical analysis}

The data were analyzed by one-way analysis of variance (ANOVA) followed by Dunnett's test for comparisons of all treatments (salt-treated or re-adapted) against the control. The value of $P<0.05$ was selected as the threshold of statistical significance and was carried out using the SAS 9.1 statistical software program (SAS Institute Inc., Cary, NC, USA).

\section{RESULTS AND DISCUSSION}

\section{Growth of Rhizophora apiculata seedlings}

The growth parameter was measured as the height and diameter of R.apiculata seedlings, a non-secretor species, thrived up to $0.5 \%$ salinity level, and then decreased with the increasing salinity level (Figure 1 A-B). The growth of $R$. apiculata seedlings was slightly lower in saline conditions as compared to that subjected to fresh water recovery (Figure 1, Figure $1 \mathrm{~A}-\mathrm{B}$, column fresh water recovery treatment from salt-treated $(0.5 \%, 1.5 \%, 2.0 \%$, and $3 \%$ ) to fresh water recovery treatment. The plant height at higher salinity levels $(2.0 \%$ and $3.0 \%$ salt concentrations) was found to significantly inhibited seedling growth (Figure $1 \mathrm{~A})$ and significantly decreased the seedling height under $3.0 \% \rightarrow 0.0 \%$. The tallest seedling $(20.1 \mathrm{~cm})$ was found under $0.5 \%$ salinity level; on the other hand, the biggest seedling diameter $(5.1 \mathrm{~mm})$ was found under $1.5 \%$ salinity treatment.

Generally, mangrove plants were tolerant of high salinity level, but between species of mangrove's tolerance to salinity was varying (Kathiresan and Thangam 1990; Basyuni et al. 2018c). Basyuni et al. (2014, 2018c) reported that the growth of $R$. stylosa, Bruguiera cylindrica, $B$. sexangula, Ceriops tagal, and $R$. apiculata decreased in salinity levels above $0.5 \%$. The present experimental indicated that, in high salinity condition, mangroves consumed more energy to maintain water balance and ion concentration than to support the primary production and growth (Clough 1984). Increased salinity would inhibit the growth of mangrove seedlings (Basyuni et al. 2009, 2012a).
In mangroves, $\mathrm{Na}^{+}$secretion from xylem was carried out through anatomical adaptation which reduced or prevented apoplastic movement of the solution from outside the root to xylem to ensure cellular membranes and transporters could determine which ions passed into xylem (Flowers and Colmer 2015). The metabolic ability of plants would be disrupted if the salt concentration was high. Salt would be concentrated in vacuoles (Flowers et al. 2015). The vacuole is a place to store cell waste and excesses minerals (Salisbury and Ross 1992).

\section{Number of leaves and leaf areas of Rhizophora apiculata seedlings}

Salinity and subsequent fresh water recovery treatments had no consistent and significant effect on the number of leaves of $R$. apiculata (Figure 1C). This result well agreed with the previous report (Kathiresan and Rajendran 2002) that salinity did not affect the number of leaves and leaf area of $R$. mucronata seedlings in India. Salinity levels of $2.0 \%, 3.0 \%$, and $3.0 \% \rightarrow 0.0 \%$ significantly decreased the number of leaves, on the other hand, many leaves of $R$. apiculata were enhanced by fresh water recovery treatment (Figure 1C, column $0.5 \% \rightarrow 0.0 \%, 1.5 \% \rightarrow 0.0 \%, 2.0 \% \rightarrow$ $0.0 \%$, and $3.0 \% \rightarrow 0.0 \%$ ). The highest number of leaves was four leaves at $1.5 \%$ salinity treatment and six leaves of the saltwater treatment after fresh water recovery treatment $(1.5 \% \rightarrow 0.0 \%)$. No significant change was noted in the leaves area of $R$. apiculata under salinity or after fresh water recovery treatment as shown in Figure 1D. The highest leaf area was $4.9 \mathrm{~cm}^{2}$ under $0.5 \%$ salinity treatment and $7 \mathrm{~cm}^{2}$ under the same treatment after fresh water recovery $(0.5 \% \rightarrow 0.0 \%)$ treatment (Figure $1 \mathrm{D})$. Either salinity or fresh water recovery treatment decreased leaf area. This result supported an earlier study on $R$. stylosa and Avicennia marina seedlings (Basyuni et al. 2014).

Wang and Nii (2000) reported that decreasing leaf surface expansion lead to the termination of leaf development when salinity concentration increased as a direct response to salinity stress. The effect of salinity on growth and changes in plant structure included the decrease of leaf size, which then reduced the absorption of nutrients and water. This would then inhibit photosynthesis, and hence resulted in stunted plant growth (Waraich et al. 2011).

\section{Biomass of Rhizophora apiculata seedlings}

Biomass $R$. apiculata seedling under various salinity levels and subsequent fresh water recovery treatments are shown in Figure 2. No statistical difference was noted in fresh and dry weights of $R$. apiculata (leaves and roots) under various salinity levels, but a significantly different stem dry weight was observed in 3\% salinity level after subsequent fresh water recovery treatment (Figure 2). High salinity level followed by freshwater recovery substantially decreased fresh stem biomass of $R$. apiculata (Figure $2 \mathrm{C}$ ). 

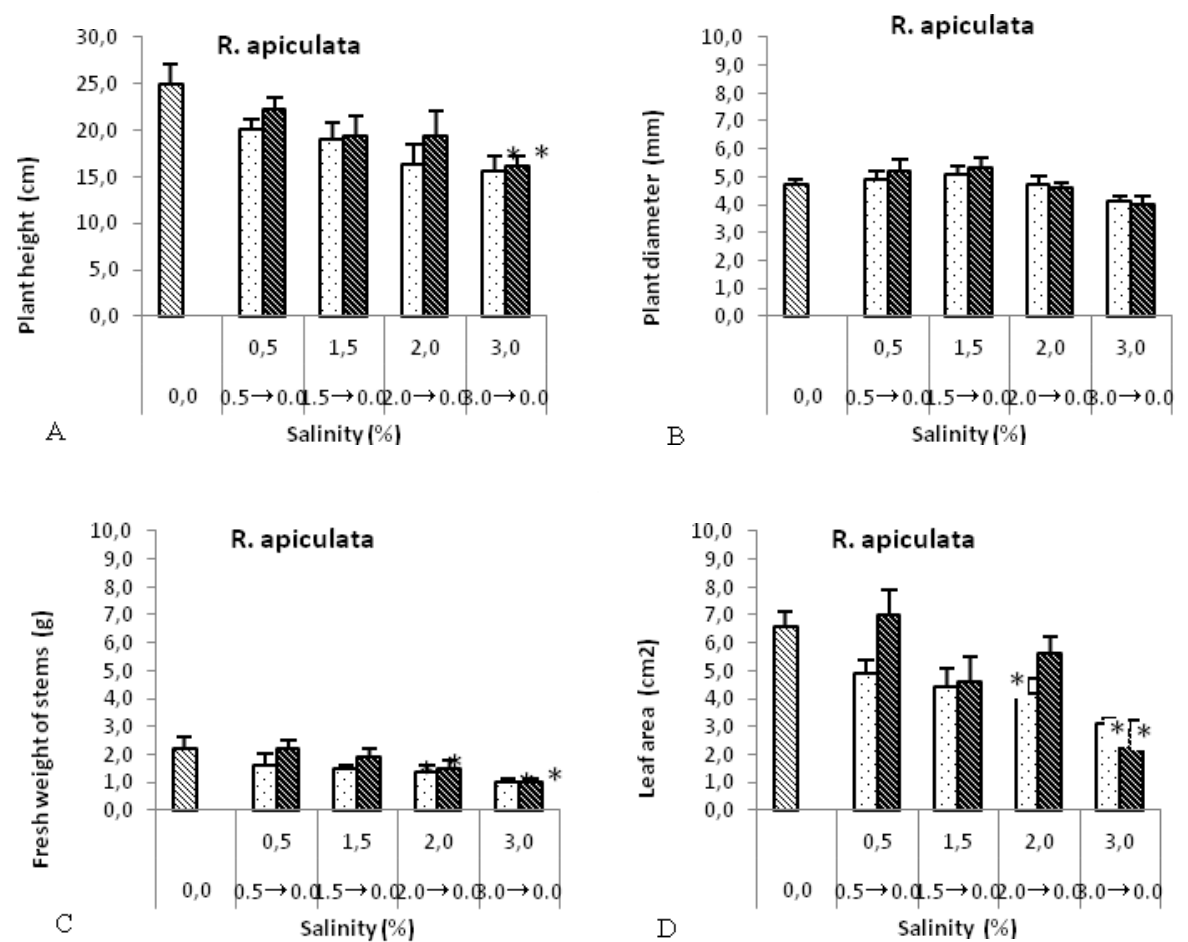

Figure 1. Effect of salinity and subsequent re-adaptation to fresh water on height (A), diameter (B), number of leaves (C), and leaf area (D) of $R$. apiculata seedlings. The data are expressed as the mean $\pm \mathrm{SE}(n=5),{ }^{*} P<0.05$ compared with the control group $(0.0 \%)$ by Dunnett's test. Control $(\mathbf{\square})$, salinity $(\square)$, re-adapted, fresh water recovery treatment $(\boldsymbol{\square})$. The arrow $(\rightarrow$ ) denotes the fresh water recovery treatment.
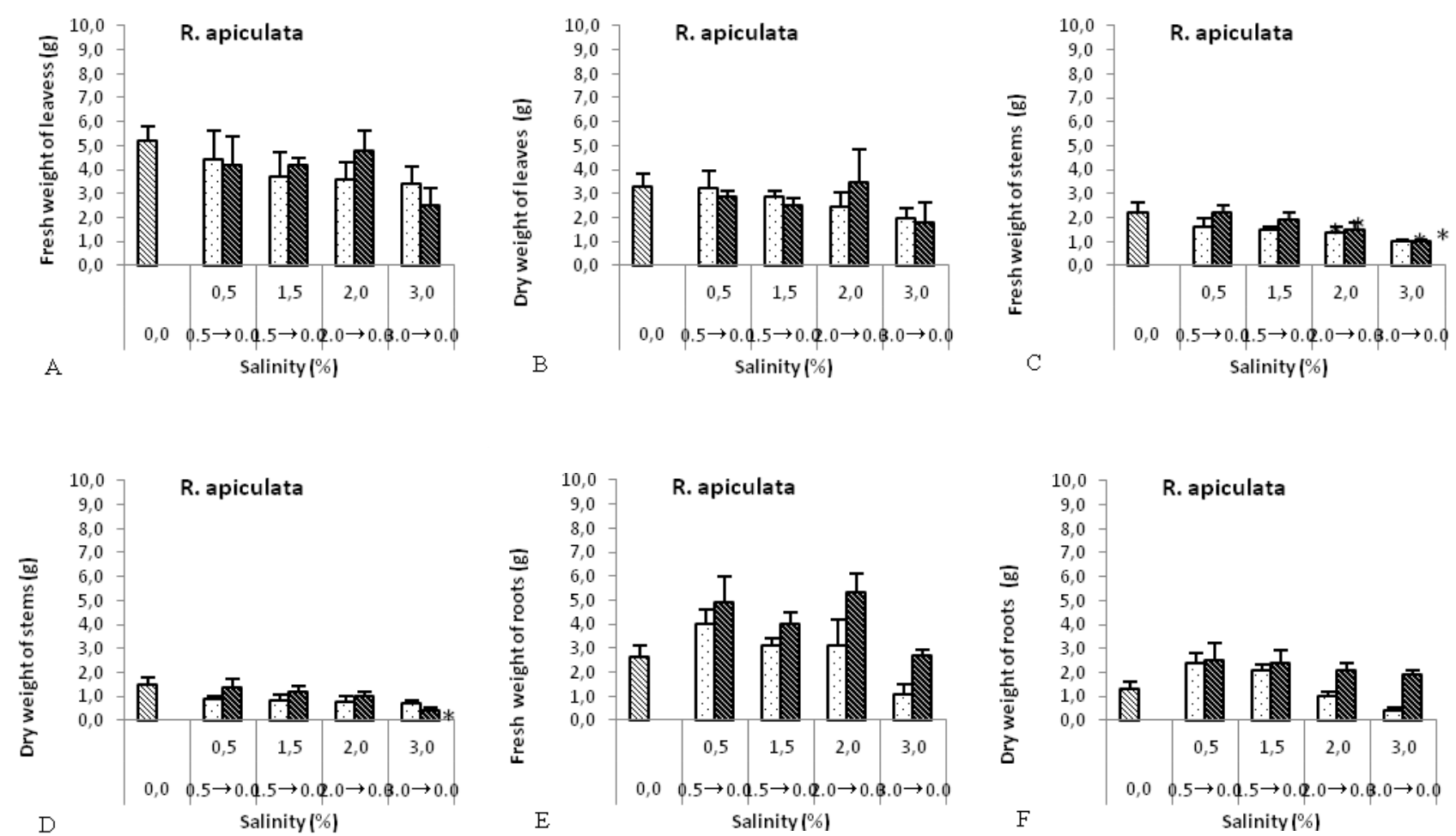

Figure 2. Effect of salinity and subsequent re-adaptation to fresh water on fresh weight of leaves (A), dry weight of leaves (B), fresh weight of stems (C), dry weight of stems (D), fresh weight of roots (E), and dry weight of roots (F) of $R$. apiculata. The data are expressed as the mean $\pm \mathrm{SE}(\mathrm{n}=5),{ }^{*} P<0.05$ compared with the control group $(0.0 \%)$ by Dunnett's test. Control $(\square)$, salinity ( $\square$ ), readapted $(\square)$ fresh water recovery treatment $(\rightarrow)$. The arrow $(\rightarrow$ ) denotes the fresh water recovery treatment 
The results showed that salinity treatment caused a decrease in fresh weight and dry weight of $R$. apiculata seedlings. Chartzoulakis and Klapaki (2000) reported that salinity stress resulted in a reduction of fresh weight and dry weight of leaves, stems, and roots. The decrease of stomata conductance was derived from reductions in leaf area as well as salinity level (Marcelis and van Hooijdonk 1999). Water potential and osmotic potential of plants were found to be negatively correlated with salinity level while turgor pressure increased with increasing salinity level (Aziz and Khan 2001). The decrease in leaf water potential and osmotic potential depended on the osmotic potential of roots (Rajasekaran et al. 2001).

\section{The occurrence and distribution of polyprenols and dolichols in Rhizophora apiculata seedlings leaves and roots}

The search for long-chain polyisoprenoids from $R$. apiculata leaves and roots was performed by 2P-TLC (Sagami et al. 1992; Basyuni et al. 2016, 2017a) to divide polyisoprenoids into polyprenol and dolichol families, which are different in carbon chain lengths. Table 1 and 2 summarised the distribution of polyprenols and dolichols along with, respectively, carbon-chain lengths of each family.

Table 1 shows the polyisoprenoid distribution in the leaves and roots of $R$. apiculata $0.0 \%, 1.5 \%, 3.0 \%$ salinity treatments and those after subsequent fresh water recovery treatments $(1.5 \% \rightarrow 0.0 \%, 3.0 \% \rightarrow 0.0 \%)$. The highest total lipid content in leaves tissues was found in $3.0 \%$ salt concentration after fresh water recovery treatment (613.9 $\mathrm{mg} / \mathrm{g} \mathrm{dw}$ ) and the lowest was under $1.5 \%$ salinity treatment $(559.2 \mathrm{mg} / \mathrm{g} \mathrm{dw})$. Whereas, the highest total lipid in roots tissues was under $0 \%$ salinity $(600.5 \mathrm{mg} / \mathrm{g} \mathrm{dw})$ and the lowest was under $1.5 \%$ salinity $(512.2 \mathrm{mg} / \mathrm{g} \mathrm{dw})$. Our $2 \mathrm{P}$ TLC analysis revealed that dolichol dominated over polyprenol (Type I distribution of polyisoprenoid) in both the leaves and roots of $R$. apiculata under salinity treatments $(0.0 \%, 1.5 \%$, and $3.0 \%)$ and those after subsequent fresh water recovery $(1.5 \% \rightarrow 0.0 \%$ and $3.0 \%$ $\rightarrow 0.0 \%)$.
Polyisoprenoids have been reported to work with unsaturated fatty acids to increase fluidity and permeability of cell membrane (Valtersson et al. 1985; Janas et al. 2000; Wallis and Browse 2002). Salinity stress affected all critical processes such as growth, photosynthesis, protein synthesis, and energy and lipid metabolism (Parida and Das 2005). Upchurch (2008) reported that polyisoprenoids, similar to fatty acids, adjusted the physicochemical properties of cell membranes by increasing the cell membrane permeability, thereby affecting the ability of plants to adapt to stressed conditions.

The distribution of secondary metabolites in plants was far more limited than the primary metabolites. The production of secondary metabolites was sometimes low ( $<1 \%$ dry weight) and depended on the plant type, physiology, and development (Coste et al. 2011). The distribution of polyprenol and dolichol in leaves could be classified into three categories, i.e., I, II, and III (Basyuni et al. 2016, 2018a). In this study, dolichol was found in all $R$. apiculata leaves and roots (Table 1). Skorupinska-Tudek et al. (2003) reported the separation of polyisoprenoid alcohol families in Coluria geoides roots to show the accumulation of a mixture of saturated and unsaturated alcohols, where dolichol ( $\alpha$-saturated) was the most dominant (Dol-16 as a form of dominance). Whereas Dol-17 was the main component of the dolichol family in $C$. geoides leaves and seeds (Skorupinska-Tudek et al. 2003). The polyisoprenoid pattern in the roots of $A$. marina, B. gymnorrhiza, E. agallocha, $H$. littoralis, and $S$. alba was found more dominant than that of polyprenol, as displayed in type-I. In leaves of A. marina, E. agallocha, H. littoralis, and S. alba, dolichol was found while the polyprenol was absent (Basyuni et al. 2016). Polyisoprenoid analysis in mangrove leaves showed that the main polyisoprenoid alcohol was not polyprenol but dolichol that was detected in old leaves of A. marina and B. gymnorrhiza leaves, and B. gymnorrhiza. Polyprenol was not detected in B. gymnorrhiza leaves (Basyuni et al. 2016). Baczewska et al. (2014) reported that the level of prenyl lipid accumulation was much higher in Tilia leaves. Thus, resistance to salt stress might share similar molecular mechanisms of polyisoprenoid involvement in plant adaptation to biotic and abiotic stresses.

Table 1. Total lipid and distribution of polyprenol and dolichol in Rhizophora apiculata leaves and roots

\begin{tabular}{|c|c|c|c|c|c|c|c|c|c|c|c|c|}
\hline \multirow{2}{*}{ Species } & \multirow{2}{*}{ Tissue } & \multirow{2}{*}{ Salinity } & \multirow{2}{*}{$\begin{array}{l}\text { Total lipid } \\
(\mathrm{mg} / \mathrm{g} \mathrm{dw})\end{array}$} & \multirow{2}{*}{$\begin{array}{c}\text { Polyisoprenoid } \\
(\mathrm{mg} / \mathrm{g} \mathrm{dw})\end{array}$} & \multicolumn{2}{|c|}{ Polyisoprenoid } & \multicolumn{3}{|c|}{$\%$ total lipid } & \multicolumn{2}{|c|}{$\%$ polyisoprenoid } & \multirow[t]{2}{*}{ Type } \\
\hline & & & & & Polyprenol (mg/g) & Dolichol (mg/g) & Polyisoprenoid & Polyprenol & Dolichol & Polyprenol & Dolichol & \\
\hline \multirow{10}{*}{ R.apiculata } & \multirow{5}{*}{ leaves } & $0.0 \%$ & $559.8 \pm 12.0$ & $25.8 \pm 5.8$ & nd & $25.8 \pm 5.8$ & 4.6 & nd & 4.6 & nd & 100.0 & I \\
\hline & & $1.5 \%$ & $559.2 \pm 8.1$ & $45.1 \pm 20.1$ & nd & $45.1 \pm 20.1$ & 8.1 & nd & 8.1 & nd & 100.0 & I \\
\hline & & $1.5 \%-0.0 \%$ & $611.1 \pm 40.6$ & $24.0 \pm 3.8$ & nd & $24.0 \pm 3.8$ & 3.9 & nd & 3.9 & nd & 100.0 & I \\
\hline & & $3.0 \%$ & $576.5 \pm 4.3$ & $116.8 \pm 31.0$ & nd & $116.8 \pm 31.0$ & 20.3 & nd & 20.3 & nd & 100.0 & I \\
\hline & & $3.0 \%-0.0 \%$ & $613.9 \pm 14.5$ & $54.2 \pm 36.6$ & nd & $54.2 \pm 36.6$ & 8.8 & nd & 8.8 & nd & 100.0 & I \\
\hline & \multirow{5}{*}{ roots } & $0.0 \%$ & $600.5 \pm 40.7$ & $57.3 \pm 19.3$ & nd & $57.3 \pm 19.3$ & 9.5 & nd & 9.5 & nd & 100.0 & I \\
\hline & & $1.5 \%$ & $521.2 \pm 50.1$ & $44.8 \pm 16.1$ & nd & $44.8 \pm 16.1$ & 8.6 & nd & 8.6 & nd & 100.0 & I \\
\hline & & $1.5 \%-0.0 \%$ & $544.0 \pm 4.6$ & $30.6 \pm 4.5$ & nd & $30.6 \pm 4.5$ & 5.6 & nd & 5.6 & nd & 100.0 & I \\
\hline & & $3.0 \%$ & $556.0 \pm 18.0$ & $128.3 \pm 24.6$ & nd & $128.3 \pm 24.6$ & 23.1 & nd & 23.1 & nd & 100.0 & I \\
\hline & & $3.0 \%-0.0 \%$ & $543.5 \pm 26.2$ & $52.5 \pm 19.7$ & nd & $52.5 \pm 19.7$ & 9.7 & nd & 9.7 & nd & 100.0 & I \\
\hline
\end{tabular}

Note: $\mathrm{nd}=$ not detected, $\mathrm{dw}=$ dry weight. Total lipid are represented as mean $\pm \mathrm{SE}(n=2-3)$. The arrow $(\rightarrow)$ denotes the fresh water recovery treatment 


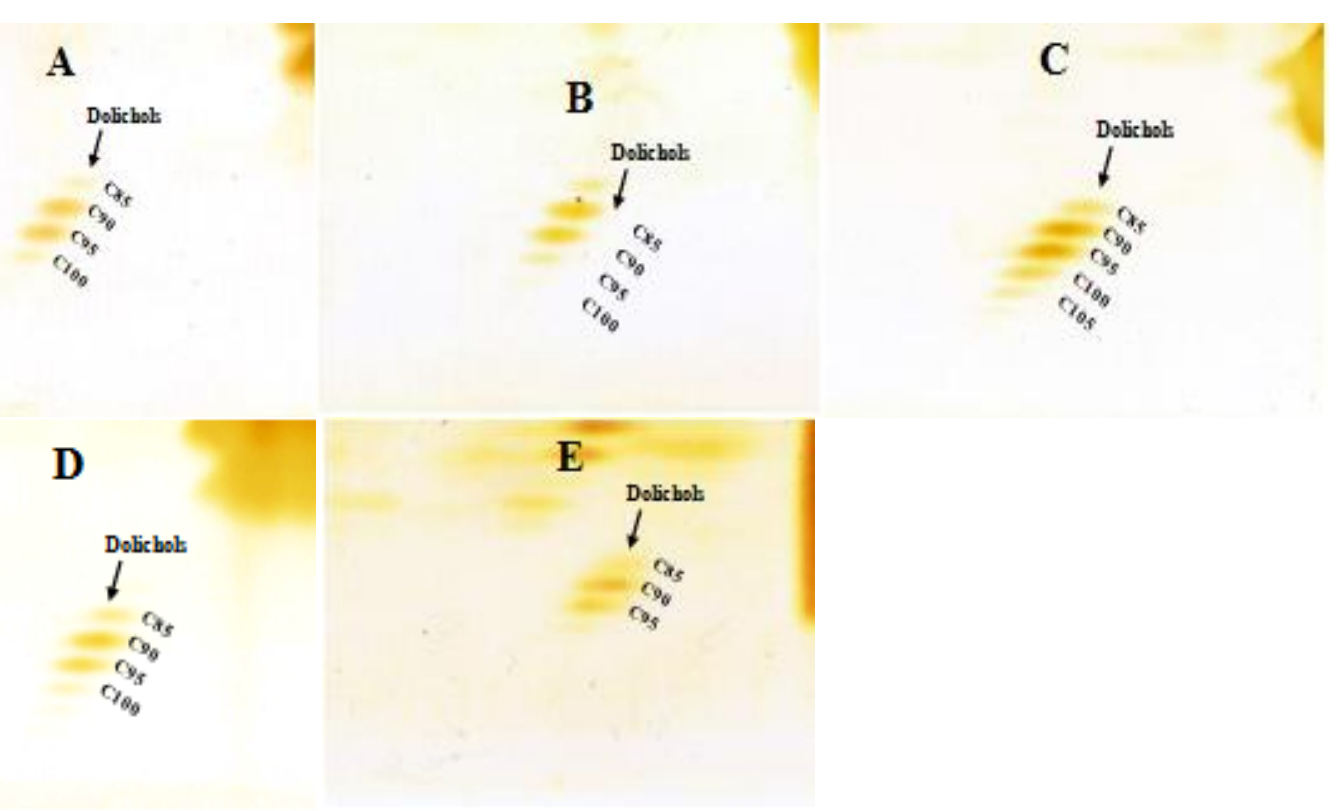

Figure 3. 2D-TLC chromatogram of polyisoprenoid from $R$. apiculata leaves under salinity level of $0.0 \%$ (A), $1.5 \%$ (B), $1.5 \% \rightarrow 0.0 \%$ $(\mathrm{C}), 3.0 \%(\mathrm{D}), 3.0 \% \rightarrow 0.0 \%(\mathrm{E})$. The carbon number refers to the carbon-chain length of polyisoprenoid alcohols. $(\rightarrow)$ : subsequent fresh water recovery treatment
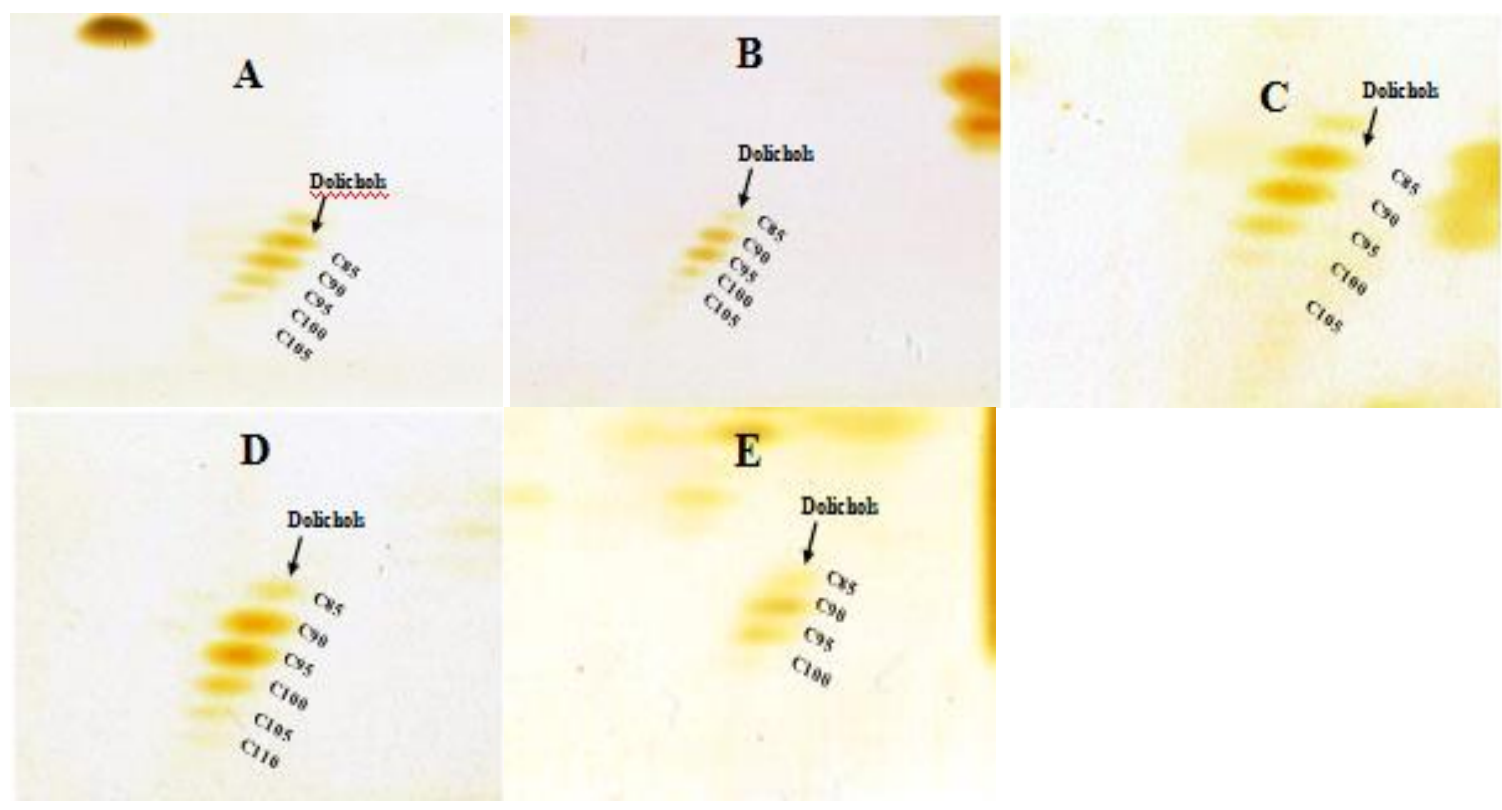

Figure 4. 2D-TLC chromatogram of polyisoprenoid from $R$. apiculata roots under salinity level of $0.0 \%(\mathrm{~A}), 1.5 \%(\mathrm{~B}), 1.5 \% \rightarrow 0.0 \%$ $(\mathrm{C}), 3.0 \%(\mathrm{D}), 3.0 \% \rightarrow 0.0 \%(\mathrm{E})$. The carbon number refers to the carbon-chain length of polyisoprenoid alcohols. $(\rightarrow)$ denotes subsequent fresh water recovery treatment

Type II shows the presence of both polyprenol and dolichol; this type of distribution was not detected in the roots and leaves of $R$. apiculata. Type III, where the polyprenol dominated dolichol, was not detected in the roots and leaves of $R$. apiculata. Figure 3 illustrated the distribution of dolichol in R. Apiculata a long with carbon chain of $\mathrm{C}_{85}-\mathrm{C}_{100}, \mathrm{C}_{85}-\mathrm{C}_{100}, \mathrm{C}_{85}-\mathrm{C}_{105}, \mathrm{C}_{85}-\mathrm{C}_{100}, \mathrm{C}_{85}-\mathrm{C}_{95}$ found at salinity concentrations of $0.0 \%, 1.5 \%, 1.5 \% \rightarrow$ $0.0 \%, 3.0 \%$, and $3.0 \% \rightarrow 0.0 \%$. The distribution of dolichol in root of R. apiculata was depicted in Table 2 and Figure 5 with carbon chain lengths of $\mathrm{C}_{85}-\mathrm{C}_{105}, \mathrm{C}_{85}-\mathrm{C}_{105}$, $\mathrm{C}_{85}-\mathrm{C}_{105}, \mathrm{C}_{85}-\mathrm{C}_{110}, \mathrm{C}_{85}-\mathrm{C}_{100}$ found at salinity concentrations of $0.0 \%, 1.5 \%, 1.5 \% \rightarrow 0.0 \%, 3.0 \%$, and $3.0 \% \rightarrow 0.0 \%$. Table 2 also showed that dolichol dominated in the root of $R$. apiculata with $\mathrm{C}_{85}-\mathrm{C}_{110}$ carbon chain length (salinity concentration of $3.0 \%$ ). It is noteworthy that polyprenol compounds were not found in the leaves and roots of $R$. apiculata. 
Table 2. Carbon-chain length of dolichol from Rhizophora apiculata leaves and roots*

\begin{tabular}{|c|c|c|c|}
\hline Species & Tissue & Salinity (\%) & Dolichol $^{*}$ \\
\hline R. apiculata & Leaves & 0 & 859095100 \\
\hline R. apiculata & Leaves & 1.5 & 859095100 \\
\hline R. apiculata & Leaves & $1.5 \rightarrow 0$ & 859095100105 \\
\hline R. apiculata & Leaves & 3 & 859095100 \\
\hline R. apiculata & Leaves & $3 \rightarrow 0$ & 859095 \\
\hline R. apiculata & Roots & 0 & 859095100105 \\
\hline R. apiculata & Roots & 1.5 & 859095100105 \\
\hline R. apiculata & Roots & $1.5 \rightarrow 0$ & 859095100 \\
\hline R. apiculata & Roots & 3 & 859095100105110 \\
\hline R. apiculata & Roots & $3 \rightarrow 0$ & 859095100 \\
\hline
\end{tabular}

Note: *The numbers refer to the carbon-chain length of polyisoprenoid alcohols. The arrow $(\rightarrow)$ denotes the fresh water recovery treatment

Figures 3 and 4 show the 2D-TLC chromatograms of polysioprenoid from leaves and roots of $R$. apiculata under $0.0 \%, 1.5 \%, 1.5 \% \rightarrow 0.0 \%, 3.0 \%$, and $3.0 \% \rightarrow 0.0 \%$ salinity treatments. In Figure 3C, longer dolichol was found under $1.5 \% \rightarrow 0.0 \%$ salinity $\left(\mathrm{C}_{85}-\mathrm{C}_{105}\right)$, and shorter dolichol was found under $3.0 \% \rightarrow 0.0 \%$ salinity (Figure $\left.3 \mathrm{D}, \mathrm{C}_{85}-\mathrm{C}_{95}\right)$. Figure $4 \mathrm{C}$ showed a longer chain length of dolichol $\left(\mathrm{C}_{85}-\mathrm{C}_{110}\right)$ was found in roots of $R$. apiculata was found but the chain-length decreased under $3.0 \% \rightarrow 0.0 \%$ salinity treatment (Figure 4D, $\mathrm{C}_{85}-\mathrm{C}_{100}$ ).

The dolichol chain length varied in each tissue of the same type of plant, and it appeared to build a different family with dominant molecule species (Tateyama et al.1999). The difference in the length of the polyisoprenoid chain found in the leaves and roots of $R$. apiculata was, presumably, caused by several factors including the increase of age (tissue aging) (Swierzewski and Danikiewicz 2005), salinity stress (Basyuni et al. 2016, 2017a,b), tissue differences (Tateyama et al., 1999; Sumacz and Swiezewska 2011), and light intensity (Swiezewska and Danikiewicz 2005; Basyuni et al. 2012b). Dolichol was found to be dominant over polyprenol in the roots of Aegiceras. corniculatum, Av. Alba, Av. lanata, Av. officinalis, $B$. parviflora, $C$. tagal, $N$. fruticans, $R$. apiculata, $R$. mucronata, $S$. caseolaris, and $X$. granatum; which is a similar type I in the leaves (Basyuni et al. 2016, 2017a). The presence of dolichol in all plant tissues (leaf, root, and flower) implied that polyprenol might not play an essential role in mangroves, although the function of polyprenol in the plant world was not well understood (Basyuni et al., 2017a). Recently, polyisoprenoid from sixteen mangrove species showed strong antimicrobial activity but did not inhibit the antifungal activity of Candida albicans (Sumardi et al. 2018). More recently, polyisoprenoid from A. marina, A. lanata, and $N$. fruticans leaves exhibited an anticancer activity of colon cells (Sari et al. 2018; Illian et al. 2018). These studies suggested that polyisoprenoids involved in biological and pharmacological properties in mangroves plants.
Dolichol was found distributed in all plant tissues, which indicates that dolichol was used as a lipid-sugar carrier in N-glycoprotein biosynthesis (Kurisaki et al. 1997; Pattison and Amtmann 2009). Dolichol was found to involve in many cellular processes. Dolichol might play an essential role in protein glycosylation and other modifications; free dolichol also had critical biological functions as lipids (Chojnacki and Dallner 1988).

In conclusion, the optimum growth of $R$. apiculata seedlings was found in $0.5 \%$ salt concentration. Salinity and re-adaptation to freshwater significantly increased the leaf area $(2.0 \%, 3.0 \%$ and $3.0 \% \rightarrow 0.0 \%)$, stem fresh weight $(3.0 \%$ and $3 \% \rightarrow 0.0 \%)$ and stem dry weight $(3 \%$ $\rightarrow 0.0 \%$ ). Distribution of polyprenols and dolichols in the leaves and roots of $R$. apiculata seedlings were categorized as type I, where dolichol was dominant over polyprenol with the dolichol carbon chain length of $\mathrm{C}_{85}-\mathrm{C}_{100}, \mathrm{C}_{85}-\mathrm{C}_{100}$, $\mathrm{C}_{85}-\mathrm{C}_{105}, \mathrm{C}_{85}-\mathrm{C}_{100}, \mathrm{C}_{85}-\mathrm{C}_{95}$ in the leaves and $\mathrm{C}_{85}-\mathrm{C}_{105}, \mathrm{C}_{85^{-}}$ $\mathrm{C}_{105}, \quad \mathrm{C}_{85}-\mathrm{C}_{105}, \quad \mathrm{C}_{85}-\mathrm{C}_{110}, \quad \mathrm{C}_{85}-\mathrm{C}_{100}$ in roots under, respectively, the salinity treatments of $0.0 \%, 1.5 \%, 3.0 \%$, and those after subsequent fresh water recovery $(1.5 \% \rightarrow$ $0.0 \%$, and $3.0 \% \rightarrow 0.0 \%$ ). The present data indicated the significant role of polyisoprenoids in the mangrove plants adaptation to withstand salt stress and or freshwater stress.

\section{ACKNOWLEDGEMENTS}

This work was funded by an International Research Collaboration and Scientific Publication Grant 2018 of the Directorate for Research and Community Service, Ministry of Research, Technology and Higher Education, Republic of Indonesia.

\section{REFERENCES}

Aziz I, Khan MA. 2001. Experimental assessment of salinity tolerance of Ceriops tagal seedlings and saplings from the Indus delta, Pakistan. Aquat Bot 70: 259-268.

Baczewska AH, Dmuchowski W, Jozwiak A, Gozdwoski D, Bragoszewska P, Dabrowski P, Swiezewska E. 2014. Effect of salt stress on prenol lipids in the leaves of Tilia 'Euchlora'. Dendrobiology 72: $177-186$

Basyuni M, Baba S, Inafuku M, Iwasaki H, Kinjo K, Oku H. 2009. Expression of terpenoid synthase mRNA and terpenoid content in salt-stressed mangrove. J Plant Physiol 166: 1786-1800.

Basyuni M, Baba S, Kinjo Y, Oku H. 2012a. Salinity increases the triterpenoid content of a salt secretor and a non-salt secretor mangrove. Aquat Bot 97: 17-23.

Basyuni M, Baba S, Kinjo Y, Putri LA, Hakim L, Oku H. 2012b. Saltdependent increase in triterpenoids is reversible upon transfer to fresh water in mangrove plants Kandelia candel and Bruguiera gymnorrhiza. J Plant Physiol 169: 1903-1908.

Basyuni M, Putri LAP, Nainggolan B, Sihaloho PE. 2014. Growth and biomass in response to salinity and subsequent fresh water in mangrove seedlings Avicennia marina and Rhizophora stylosa. J Manajemen Hutan Tropika 20: 17-25.

Basyuni M, Sagami H, Baba S, Iwasaki H, Oku H. 2016. Diversity of polyisoprenoid in ten Okinawan mangroves. Dendrobiology 75: 167175.

Basyuni M, Sagami H, Baba S, Oku H. 2017a. Distribution, occurrence, dan cluster analysis of new polyprenyl acetones and other 
polyisoprenoids from North Sumatran mangroves. Dendrobiology 78: 18-31.

Basyuni M, Sagami H, Baba S, Putri LAP, Wati R, Oku H. 2017b. Salinity alters the polyisoprenoid alcohol content and composition of both salt-secreting and non-salt-secreting mangrove seedlings. Hayati J Biosci 24: 206-2014.

Basyuni M, Wati R, Sagami H, Sumardi, Baba S, Oku H. 2018a. Diversity and abundance of polyisoprenoid composition in coastal plant species from North Sumatra, Indonesia. Biodiversitas 19: 1-11.

Basyuni M, Keliat DA, Lubis MU, Manalu NB, Syuhada A, Wati R. $2018 \mathrm{~b}$. Growth and root development of four mangrove seedlings under varying salinity. IOP Conf Ser: Earth Environ Sci 130: 012027.

Chartzoulakis K, Klapaki G. 2000. Response of two greenhouse pepper hybrids to $\mathrm{NaCl}$ salinity during different growth stages. Sci Hort 86 : 247-260.

Chojnacki T, Dallner G. 1988. The biological role of dolichol. Biochemistry 251: 1-9.

Clough BF. 1984. Growth and salt balance in the mangroves Avicennia marina (Forsk.)Vierh. and Rhizophora stylosa Griff. in relation to salinity. Aust J Plant Physiol 11: 419-430.

Coste A, Vlase L, Halmagyi A, Deliu C, Coldea G. 2011. Effects of plant growth regulators and elicitors on production of secondary metabolites in shoot cultures of Hypericum hirsutum and Hypericum maculatum. Plant Cell Tissue Organ Cult 106: 279-288.

Flowers TJ, Colmer TD. 2015. Plant salt tolerance: adaptations in halophytes. Ann Bot 115: 327-331.

Flowers TJ, Munns R, Colmer TD2015. Sodium chloride toxicity and the cellular basis of salt tolerance in halophytes. Ann Bot 115: 419-431.

Giri C, Ochieng E, Tieszen LL, Zhu Z, Singh A, Loveland T, Masek J, Duke N. 2011. Status and distribution of mangrove forests of the world using earth observation satellite data. Global Ecol Biogeogr 20: 154-159.

Illian DH, Basyuni M, Wati R, Hasibuan PAZ. 2018. Polyisoprenoids from Avicennia marina and Avicennia lanata inhibit WiDr cells proliferation. Pharmacogn Mag 14: 513-518

Ishiguro T, Morita-Fujimira Y, Shidoji Y, Sagami H. 2014. Dolichol biosynthesis: The occurrence of epoxy dolichol in skipjack tuna liver. Biochem Biophys Res Commun 451: 277-281.

Janas T, Walinska K, Chojnacki T, Swiezewska E. 2000. Modulation of properties of phospholipid membranes by the long-chain polyprenol (C160). Chem Phys Lipids 106: 31-40.

Kathiresan K, Thangam TS 1990. A note on the effects of salinity and $\mathrm{pH}$ on growth of Rhizophora seedlings. Ind For116: 243-244.

Kathiresan K, Bingham BL. 2001. Biology of mangroves and mangrove ecosystems. Adv Mar Biol 40: 81-251.

Kathiresan K, Rajendran N. 2002. Growth of mangrove (Rhizophora apiculata) seedlings as influenced by GA3, light and salinity. Rev Biol Trop 50: 525-530.

Kurisaki A, Sagami H, Ogura K. 1997. Distribution of polyprenols and dolichols in soybean plant. Phytochemistry 44: 45-50.

Marcelis LFM, van Hooijdonk J. 1999. Effect of salinity on growth, water use and nutrient use in radish (Raphanus sativus L.). Plant Soil 215: $57-64$
Parida AK, Das AD. 2005. Salt tolerance and salinity effects on plants: a review. Ecotoxicol Environ Saf 60: 324-349.

Parida AK, Jha B. 2010. Salt tolerance mechanisms in mangroves: a review. Trees 24: 199-217.

Pattison RJ, Amtmann A. 2009. N-glycan production in the endoplasmic reticulum of plants. Trends Plant Sci 14: 92-99.

Rajasekaran LR. Aspinall D. Jones GP, Paleg LG. 2001. Stress metabolism. IX. Effect of salt stress on trigonelline accumulation in tomato. Can J Plant Sci 81: 487-498.

Sagami H, Kurisaki A, Ogura K, Chojnacki T. 1992. Separation of dolichol from dehydrodolichol by a simple two-plate thin layer chromatography. J Lipid Res 33: 1857-1861.

Sagami H, Swiezewska E, Shidoji Y. 2018. The history and recent advances in research of polyprenol and its derivatives. Biosci Biotechnol Biochem 82: 947-955.

Salisbury FB, Ross CW. 1992. Plant Physiology. Wadsworth Publishing.

Sari DP, Basyuni M, Hasibuan PAZ, Wati R 2018 The inhibition of polyisoprenoids from Nypa fruticans leaves on cyclooxygenase 2 expressions of WiDr colon cancer cells. Asian J Pharm Clin Res 11: 154-157.

Schneider CA, Rasband WS, Eliceiri KW. 2012. NIH Image to ImageJ: 25 years of image analysis. Nature Methods 9: 671-675.

Skorupinska-Tudek K, Bienkowski T, Olszowska O, Furmanowa M, Chojnacki T, Danikiewicz W, Swiezewska E. 2003. Divergent pattern of polyisoprenoid alcohols in the tissues of Coluria geoides: a new electrospray ionization MS approach. Lipids 38: 981-990.

Sumardi S, Basyuni M, Wati R. 2018. Antimicrobial activity of polyisoprenoids of sixteen mangrove species from North Sumatra, Indonesia. Biodiversitas 19: 1243-1248.

Surmacz L, Swiezewska E. 2011. Polyisoprenoids - Secondary metabolites or physiologically important superlipids? Biochem Biophys Res Commun 407: 627-32.

Swiezewska E, Danikiewicz W. 2005. Polyisoprenoids: Structure, biosynthesis and function. Prog Lipid Res 44: 235-258.

Tateyama S, Wititsuwannakul W, Wititsuwannakul D, Sagami H, Ogura K. 1999. Dolichols of rubber plant, ginkgo, and pine. Phytochemistry 51: 11-15.

Upchurch RG 2008. Fatty acid unsaturation, mobilization, and regulation in response of plants to stress. Biotechnol Lett30: 967-977.

Valtersson C, van Duyn G, Verkleij AJ, Chojnacki T, de Kruijff B, Dallner G. 1985. The influence of dolichol, dolichyl esters, and dolichyl phosphate on phospholipid polymorphism and fluidity in model membranes. JBiol Chem 260: 2742-2751.

Wallis JG, Browse J. 2002. Mutants of Arabidopsis reveal many roles for membrane lipids. Prog Lipid Res 41: 254-278.

Wang Y, Nii N. 2000. Changes in chlorophyll, ribulose bisphosphate carboxylase-oxygenase, glycine betaine content, photosynthesis and transpiration in Amaranthus tricolor leaves during salt stress. J Hortic Sci Biotechnol75: 623-627.

Waraich EA, Ahmad R, Ashraf MY. 2011. Role of mineral nutrition in alleviation of drought stress in plants. Aust J Crop Sci 5: 764. 